\title{
Review \\ Clinical Utility of Biosensing Platforms for Confirmation of SARS-CoV-2 Infection
}

\author{
Le Minh Tu Phan ${ }^{1,2,+} \mathbb{D}$, My-Van Tieu ${ }^{3,+}$, Thi-Thu Pham ${ }^{2}$ and Sungbo Cho 1,4,*(D) \\ 1 Department of Electronic Engineering, Gachon University, Seongnam-si 13120, Korea; plmtu@smp.udn.vn \\ 2 School of Medicine and Pharmacy, The University of Danang, Danang 550000, Vietnam; ptthu@smp.udn.vn \\ 3 TST Trading Service Technology Co., Ltd., Hochiminh City 723000, Vietnam; myvantieucau@gmail.com \\ 4 Department of Health Sciences and Technology, GAIHST, Gachon University, Incheon 21999, Korea \\ * Correspondence: sbcho@gachon.ac.kr \\ + These authors contributed equally to this work.
}

Citation: Phan, L.M.T.; Tieu, M.-V.; Pham, T.-T.; Cho, S. Clinical Utility of Biosensing Platforms for

Confirmation of SARS-CoV-2

Infection. Biosensors 2021, 11, 167

https://doi.org/10.3390/

bios11060167

Received: 10 April 2021

Accepted: 21 May 2021

Published: 24 May 2021

Publisher's Note: MDPI stays neutral with regard to jurisdictional claims in published maps and institutional affiliations.

\begin{abstract}
Despite collaborative efforts from all countries, coronavirus disease 2019 (COVID-19) pandemic has been continuing to spread globally, forcing the world into social distancing period, making a special challenge for public healthcare system. Before vaccine widely available, the best approach to manage severe acute respiratory syndrome coronavirus 2 (SARS-CoV-2) infection is to achieve highest diagnostic accuracy by improving biosensor efficacy. For SARS-CoV-2 diagnostics, intensive attempts have been made by many scientists to ameliorate the drawback of current biosensors of SARS-CoV-2 in clinical diagnosis to offer benefits related to platform proposal, systematic analytical methods, system combination, and miniaturization. This review assesses ongoing research efforts aimed at developing integrated diagnostic tools to detect RNA viruses and their biomarkers for clinical diagnostics of SARS-CoV-2 infection and further highlights promising technology for SARS-CoV-2 specific diagnosis. The comparisons of SARS-CoV-2 biomarkers as well as their applicable biosensors in the field of clinical diagnosis were summarized to give scientists an advantage to develop superior diagnostic platforms. Furthermore, this review describes the prospects for this rapidly growing field of diagnostic research, raising further interest in analytical technology and strategic plan for future pandemics.
\end{abstract}

Keywords: SARS-CoV-2; COVID-19 clinical diagnostics; nucleic acid amplification; RT-PCR; RTLAMP; optical biosensor; lateral flow assay; ELISA; electrochemical biosensor; lab-in-a-tube

\section{Introduction}

The coronavirus disease 2019 (COVID-19) pandemic has highlighted the importance of the prompt and sensitive diagnosis of viral infections to enable effective tracing and implementation of public health measures for the prevention and management of outbreaks. Severe acute respiratory syndrome coronavirus-2 (SARS-CoV-2) can transmit directly to human by droplets, causing the slight-to-severe symptoms of respiratory infections in humans [1,2]. In 2002 and 2012, there were two human coronaviruses transmitted from animals to human to cause acute respiratory disease with high pathogenicity including Severe Acute Respiratory Syndrome (SARS) and Middle East Respiratory Syndrome (MERS), and current highly pathogenic SARS-CoV-2 has been making the outbreak of the global COVID19 pandemic since December 2019 [3-5]. In January 2020, China was the first country to confirm viral deaths, and the number of deaths exceeded 100, with infections increasing rapidly [6]. Countries worldwide are currently dealing with this virus, and at least 47 other countries and territories were declared infected with SARS-CoV-2 in February 2020 [7]. As the number of viral deaths worldwide surpassed 10,000, concern shifted to Europe, especially Italy [8]. At the end of March 2020, the number of confirmed cases of COVID-19 in Korea was approximately 10,000 due to a large outbreak in the city of Daegu 150 miles southeast of Seoul [9]. Simultaneously, in India, people were instructed to remain indoors 
unless there was an emergency [10]. A new milestone of 1,000,000 deaths was reached in September 2020. According to Johns Hopkins University, as of the 8th November this included 236,073 cases in the USA, 161,106 in Brazil, and 125,562 in India [11]. At present (November 7th 2020), the World Health Organization (WHO) states that there are currently $49,765,123$ cases with 1,250,160 deaths and 35,315,721 patients recovered to date [12].

In late 2019, severe respiratory distress with pneumonia-like symptoms was reported in Wuhan, China. This virus, as of animal origin, was named SARS-CoV-2 or more commonly, the novel coronavirus, resulting in the acute respiratory infection as COVID-19 [13]. In the early stages, these undocumented viral infections often go undetected due to mild or limited symptoms. Their comparatively high ability to spread and high prevalence caused a large proportion of the global population to be exposed to the virus [14]. At present, there is no specific treatment but multiple effective vaccines being administered worldwide. Immediate action from both academia and industry has led to the development of multiple COVID-19 diagnostic systems that have gained rapid regulatory approval and have been used clinically since their establishment $[15,16]$. This has led to the development of powerful and accurate analytical tools that use biosensors for biomarker detection. Integrated approaches offer a better standpoint for the development of biosensors during the COVID-19 pandemic.

Based on international experience, most countries worldwide have identified the five following prerequisites for relaxing COVID-19 containment and restriction measures: knowledge of contagiousness of the infection, community participation, adequate health system capacity, and border control [17]. In this review, we present the importance of using biosensor systems and their effectiveness in COVID-19 diagnosis. Different types of biosensors and integrated techniques of biosensors with diverse potential applications are needed. Therefore, this review provides an overview of the different types of biosensors being used to detect SARS-CoV-2: optical sensing, electrical sensing, lab-in-a-tube sensing system, lab-on-a-chip sensing system, electrochemical sensing, and nucleic acid amplification (NAA) sensing technique. These biosensors have made huge contributions to the diagnosis and treatment of COVID-19.

\section{Virology of SARS-CoV-2 and Its Specific Biomarkers for Diagnostics}

SARS-CoV-2 belongs to the genus Betacoronavirus (subgenus Sarbecovirus) of the family Coronaviridae and is an encapsulated positive-single-stranded RNA virus. Its capsid is encapsulated in a lipid bilayer, and the viral genome, not complementary sequences, encodes viral proteins $[18,19]$. To date, four coronaviruses $(a, b, g$, and $d)$ have been identified: human coronavirus (HCoV)-229E, HCoV-NL63, HCoV-HKU1, and HCoVOC43 $[20,21]$. The isolated novel b-CoV shows $88 \%$ homogeneity with sequences of two bat-derived coronaviruses-bat-SL-CoVZC45 and bat-SL-CoVZXC21-and shows approximately $50 \%$ sequence identity with the sequences of MERSPeer CoV. The SARSCoV-2 genome has a length of $26-32 \mathrm{~kb}$, which is the largest of all RNA viruses [18,21]. Infectious SARS-CoV-2 (diameter $\sim 100 \mathrm{~nm}$ ) contains the 29,903 nucleotide RNA genome along with four structural proteins: spike (S), envelope small membrane (E), nucleocapsid $(\mathrm{N})$, and membrane protein $(\mathrm{M})$. The N proteins bind to the RNA genome in a helical, symmetrical manner, like particles on a string, and this genome structure is surrounded by a lipid bilayer that binds to the E, M, and S proteins [22-24]. The encapsulation of genomic RNA with structural proteins leads to the formation of new SARS-CoV. The diagnostic methods of COVID-19 confirmation are mainly based on NAA techniques for RNA detection of SARS-CoV-2 as well as optical and electrochemical diagnostic biosensors for SARS-CoV-2 protein antigens (Figure 1). Antigen expression then stimulates cellular and humoral immunity of the body mediated by virus-specific B and T cells. Similar to conventional acute viral infections, the antibody profile against SARS-CoV-2 follows a typical IgM and IgG production pattern. SARS-specific IgM antibodies disappear after 12 weeks, while IgG antibodies can persist for a long time, suggesting that SARS-specific IgG antibodies, mainly S- and N-specific antibodies, play a protective role in primary 
immune response against SARS [25]. Long et al.2020 studied the antibody response to SARS-CoV-2 infection in 285 patients with COVID-19 in China. Seroconversion for IgM and IgG occurred concurrently or sequentially, and the mean day of seroconversion for immunoglobulins was 13 days after the onset of COVID-19 symptoms. After 19 days of symptom attack, a 100\% IgG seroconversion rate was noted [26]. Notably, antibody response and viral clearance may be delayed in immunocompromised individuals and those subsequently infected with SARS-CoV-2 [27]. Table 1 was created after reviewing the viral structure and immune response against SARS-CoV-2 to provide an overview of the advantages and disadvantages of its biomarkers as target analytes for applicable biosensors to confirm SARS-CoV-2 infection.

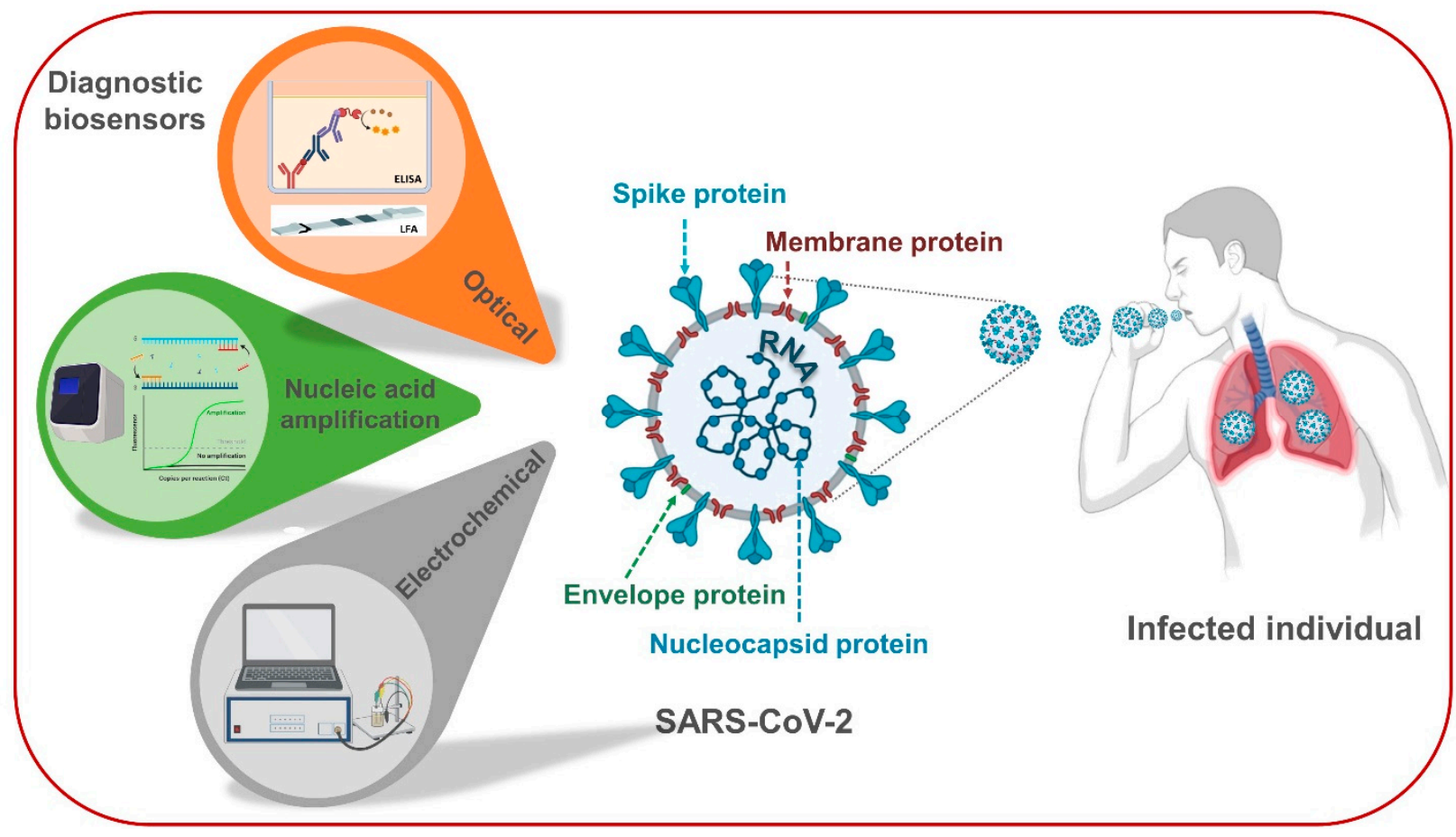

Figure 1. Structural models of SARS-CoV-2 and its developed diagnostic platforms. The subgenomic RNAs of the genome encode the following four main structural proteins: Spike protein (S), Envelope small membrane protein (E), nucleocapsid protein $(\mathrm{N})$, and membrane protein $(\mathrm{M})$, as well as several accessory proteins. Schematic representation of an ideal sensing platform composed of nucleic acid amplification technique, optical, and electrochemical sensing platforms. The general configuration of the different sensing platforms for SARS-CoV-2 detection is illustrated. 


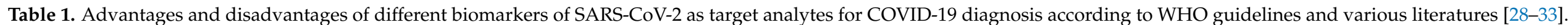

\begin{tabular}{|c|c|c|c|c|}
\hline No. & Target Analyte & Biosensor Platforms & Advantages & Disadvantages \\
\hline 1 & Antigen & $\begin{array}{l}\text { Optical sensing, ELISA, lateral flow } \\
\text { assay, aptasensing, Lab-in-a Tube } \\
\text { sensing system, Lab-on-a Chip sensing } \\
\text { system, and Electrochemical sensing. }\end{array}$ & $\begin{array}{l}\text { - Diagnostic tests are usually completed within } 30 \mathrm{~min} \text {. } \\
\text { - Detect current infection with high sensitivity } \\
\text { and specificity. } \\
\text { - Promote to determine which antigen is being } \\
\text { developed or commercialized, demonstrating } \\
\text { acceptable production in typical field studies. }\end{array}$ & $\begin{array}{l}\text { - Less sensitivity due to no target amplification process. } \\
\text { - False positive results if the antibodies also } \\
\text { acknowledge antigens from viruses other than } \\
\text { SARS-CoV-2. } \\
\text { - Depend on the sensitivity and specificity of antigens. } \\
\text { - Confirmatory tests should take place }\end{array}$ \\
\hline 2 & Antibody & $\begin{array}{l}\text { Optical sensing, ELISA, lateral flow } \\
\text { assay, aptasensing, Lab-in-a Tube } \\
\text { sensing system, Lab-on-a Chip sensing } \\
\text { system, and Electrochemical sensing. }\end{array}$ & $\begin{array}{l}\text { - Maintain an investigation of an in-progress outbreak } \\
\text { and supports backdated assessment of the attack rate } \\
\text { or size of an outbreak. } \\
\text { - Robust and faster in critically ill patients than in } \\
\text { patients with milder illness or asymptomatic infection. } \\
\text { - No need for immune genetics purification } \\
\text { before testing. }\end{array}$ & $\begin{array}{l}\text { - Costly and time-consuming. } \\
\text { - Possible only in the recovery phase. } \\
\text { - Not indicated for acute diagnosis and clinical } \\
\text { administration, and their epidemiological role is under } \\
\text { investigation. } \\
\text { - Not ensure that these are is neutralizing or protective } \\
\text { antibodies. } \\
\text { - The lifetime of the antibodies produced in response to } \\
\text { SARS-CoV-2 remains to be clarified. }\end{array}$ \\
\hline 3 & RNA & Nucleic acid amplification techniques & $\begin{array}{l}\text { - Standard diagnostic test to confirm SARS-CoV-2 } \\
\text { infection. } \\
\text { - High binding affinity, simple synthesis method, and } \\
\text { easy maintenance. } \\
\text { - Potential performance benefits, rapid data sharing, as } \\
\text { well as urgent regulatory review of possible, } \\
\text { well-functioning trials are recommended to increase } \\
\text { accessibility to SARS-CoV-2 testing. } \\
\text { - Target molecules identified by shape and sequence } \\
\text { can be detected more simply. }\end{array}$ & $\begin{array}{l}\text { - False negative results since SARS-CoV-2 continues to } \\
\text { have genetic changes over time, misconnected between } \\
\text { primers and probes. } \\
\text { - RNA should be re-examined by experienced } \\
\text { personnel and re-extracted from the original samples. } \\
\text { - Swab specimens taken at the late stages of the disease } \\
\text { or from the body cavity may not contain virus. } \\
\text { - Specimen is not always properly handled and/or } \\
\text { transported. } \\
\text { - Different viral load in different specimens } \\
\text { - Difficulty in genomic diversity and mutations } \\
\text { of virus. }\end{array}$ \\
\hline
\end{tabular}




\section{Case Studies of Biosensing Technologies for SARS-CoV-2 in Clinical}

COVID-19 viral disease is officially global pandemic, currently accounting for the highest number of deaths worldwide. Special screening is extremely important as an effective way to monitor and manage the pandemic before reaching herb immunity through effective vaccination against SARS-CoV-2. A rapid population control task for COVID-19 has been documented using innovative methods in biosensor development [34]. Biosensors are selected as promising detection devices with enormous potential as point-of-care (POC) tools to confirm the SARS-CoV-2 infection. Timely testing also helps to effectively allocate medical resources and save time for frontline medical staff. Hence, simple, rapid, cost-effective, and accessible detection techniques as POC diagnostics for large-scale screening and field testing of SARS-CoV-2 infection is important and should urgently be expedited to control the rapid and contagious spread of COVID-19. The developed sensing platforms were summarized in Table 2 in term of target analytes, sensing performance, analytical/clinical sensitivity and specificity, and commercial products, including optical biosensor (enzymelinked immunosorbent assay (ELISA) or lateral flow assay (LFA)), lab-in-a-tube sensing system, lab-on-a-chip system, electrochemical sensing, and NAA-based techniques. This table will give an overview of significant achievement in the current sensing platforms for the accurate diagnosis of COVID-19, suggesting the suitable selection of applicable approaches all over the world. 
Table 2. Reported studies of NAA-based techniques and various biosensors for the confirmation of SARS-CoV-2 infection.

\begin{tabular}{|c|c|c|c|c|c|c|c|c|c|c|c|}
\hline No. & Type of Sensing & Detection Platform & $\begin{array}{l}\text { Recognition } \\
\text { Element }\end{array}$ & $\begin{array}{l}\text { Detection Range/ } \\
\text { Qualitative }\end{array}$ & $\begin{array}{l}\text { Limit of Detection } \\
\text { (LOD) }\end{array}$ & $\begin{array}{l}\text { Detection } \\
\text { Time }\end{array}$ & $\begin{array}{l}\text { Real Sample or } \\
\text { Specimens }\end{array}$ & $\begin{array}{l}\text { Analytical/Clinical } \\
\text { Sensitivity \% }\end{array}$ & $\begin{array}{l}\text { Analytical/Clinical } \\
\text { Specificity \% }\end{array}$ & $\begin{array}{c}\text { Device/ } \\
\text { Commercial } \\
\text { Product }\end{array}$ & Ref. \\
\hline 1 & NAA & RT-PCR & RNA & $\begin{array}{l}\text { E gene assay: } 2.8-9.8 \\
\text { copies/reaction } \\
\text { RdRp assay: } 2.7-11.2 \\
\text { copies/reaction }\end{array}$ & $\begin{array}{l}\text { E gene assay: } 3.9 \\
\text { copies/reaction } \\
\text { RdRp assay: } 3.6 \\
\text { copies/reaction }\end{array}$ & $25 \mathrm{~min}$ & $\begin{array}{l}\text { Sputum, nose, } \\
\text { and throat } \\
\text { swabs }\end{array}$ & - & - & $\begin{array}{l}\text { E gene assay } \\
\text { RdRp assay }\end{array}$ & [35] \\
\hline 2 & NAA & PCR & RNA & $32.5-1042$ copies $/ \mathrm{mL}$ & $\begin{array}{l}100 \text { copies } / \mathrm{mL} \text {, } \\
242 \text { copies } / \mathrm{mL} \\
250 \text { copies } / \mathrm{mL} \\
125 \text { genome } \\
\text { equivalents } / \mathrm{mL}\end{array}$ & $\begin{array}{l}8 \mathrm{~h} \\
90 \mathrm{~min} \\
45 \mathrm{~min} \\
5-15 \mathrm{~min}\end{array}$ & $\begin{array}{l}\text { Nasopharyngeal } \\
\text { and nasal swab }\end{array}$ & $\begin{array}{l}94 \\
88 \\
100 \\
69\end{array}$ & $\begin{array}{l}100 \\
100 \\
97 \\
100\end{array}$ & $\begin{array}{l}\text { Abbott RealTime } \\
\text { m2000 } \\
\text { SARS-CoV-2 } \\
\text { Assay } \\
\text { DiaSorin } \\
\text { Simplexa } \\
\text { COVID-19 } \\
\text { Direct } \\
\text { Cepheid Xpert } \\
\text { Xpress } \\
\text { SARS-CoV-2 } \\
\text { Abbott ID NOW } \\
\text { COVID-19. }\end{array}$ & [36] \\
\hline 3 & NAA & RT-PCR & RNA & Positive and negative & - & - & $\begin{array}{l}\text { Oropharyngeal } \\
\text { swabs }\end{array}$ & $\begin{array}{l}100 \\
100\end{array}$ & $\begin{array}{l}100 \\
95.5\end{array}$ & $\begin{array}{l}\text { MagNA Pure } \\
\text { QIAcube }\end{array}$ & [37] \\
\hline 4 & NAA & $\begin{array}{l}\text { 1-Step Quantitative } \\
\text { RT-PCR }\end{array}$ & RNA & $\begin{array}{l}2 \times 10^{-4}-2000 \\
\text { TCID }_{50} / \text { reaction }\end{array}$ & $<10$ copies/reaction & $90 \mathrm{~min}$ & $\begin{array}{l}\text { Human clinical } \\
\text { specimens }\end{array}$ & - & - & - & [38] \\
\hline 5 & NAA & RT-LAMP & RNA & Positive and negative & 42 copies/reaction & $60 / 90 \mathrm{~min}$ & $\begin{array}{l}\text { Nasopharyngeal } \\
\text { swabs } \\
\text { sputum/deep } \\
\text { throat saliva } \\
\text { throat swab }\end{array}$ & $\begin{array}{l}96.88 / 98.96 \\
94.03 / 97.02 \\
93.33 / 98.33\end{array}$ & $\begin{array}{l}100 \\
100 \\
100\end{array}$ & - & [40] \\
\hline 7 & $\begin{array}{l}\text { NAA } \\
\text { colorimetry }\end{array}$ & $\begin{array}{l}\text { Colorimetric RT-LAMP } \\
\text { Swab-to-RT-LAMP } \\
\text { without RNA isolation }\end{array}$ & $\begin{array}{l}\text { RNA } \\
\text { RNA }\end{array}$ & Positive and negative & $\begin{array}{l}100 \text { RNA } \\
\text { molecules/reaction }\end{array}$ & $>30-35 \mathrm{~min}$ & $\begin{array}{l}\text { Nasopharyngeal } \\
\text { swabs }\end{array}$ & $\begin{array}{l}97.5 \\
99.5\end{array}$ & $\begin{array}{l}99.7 \\
86\end{array}$ & - & [41] \\
\hline 8 & NAA-Optical & RT-LAMP-LFAs & RNA & $\begin{array}{l}1.2 \times 10^{1}-1.2 \times 10^{4} \\
\text { copies per reaction }\end{array}$ & 12 copies/reaction & $1 \mathrm{~h}$ & $\begin{array}{l}\text { Oropharynx } \\
\text { swab samples }\end{array}$ & 100 & 100 & - & [42] \\
\hline 9 & NAA-Optical & $\begin{array}{l}\text { CRISPR-Cas12-based } \\
\text { LFAs }\end{array}$ & RNA & $0-25,000$ copies $/ \mu \mathrm{L}$ & 10 copies $/ \mu \mathrm{L}$ & $40 \mathrm{~min}$ & $\begin{array}{l}\text { Nasopharyngeal } \\
\text { and } \\
\text { oropharyngeal } \\
\text { swab }\end{array}$ & - & - & - & [43] \\
\hline
\end{tabular}


Table 2. Cont.

\begin{tabular}{|c|c|c|c|c|c|c|c|c|c|c|c|}
\hline No. & Type of Sensing & Detection Platform & $\begin{array}{l}\text { Recognition } \\
\text { Element }\end{array}$ & $\begin{array}{l}\text { Detection Range/ } \\
\text { Qualitative }\end{array}$ & $\begin{array}{l}\text { Limit of Detection } \\
\text { (LOD) }\end{array}$ & $\begin{array}{l}\text { Detection } \\
\text { Time }\end{array}$ & $\begin{array}{l}\text { Real Sample or } \\
\text { Specimens }\end{array}$ & $\begin{array}{l}\text { Analytical/Clinical } \\
\text { Sensitivity \% }\end{array}$ & $\begin{array}{l}\text { Analytical/Clinical } \\
\text { Specificity \% }\end{array}$ & $\begin{array}{c}\text { Device/ } \\
\text { Commercial } \\
\text { Product }\end{array}$ & Ref. \\
\hline 10 & Optical & $\begin{array}{l}\text { Colorimetric } \\
\text { LFAs/ELISA }\end{array}$ & Antibodies & Positive and negative & - & $10 / 120 \mathrm{~min}$ & Serum, plasma & $\begin{array}{l}84 \\
65 \\
84 \\
73\end{array}$ & $\begin{array}{l}99 \\
78 \\
91 \\
96\end{array}$ & $\begin{array}{l}\text { LFAs Biosynex } \\
\text { LFAs Servibio } \\
\text { ELISA } \\
\text { Euroimmun } \\
\text { ELISA EDI }\end{array}$ & [44] \\
\hline 11 & Optical & Colorimetric LFAs & $\begin{array}{l}\text { SARS-CoV-2 } \\
\text { nucleocapsid } \\
\text { protein }\end{array}$ & $\begin{array}{l}\text { - Genemedi } \mathrm{N} \\
\text { protein: } 0.53-0.77 \\
\text { ng/mL. } \\
\text { - Genscript N protein: } \\
0.00-7.44 \mathrm{ng} / \mathrm{mL}\end{array}$ & $\begin{array}{l}\text { - Genemedi } \mathrm{N} \\
\text { protein: } 0.65 \mathrm{ng} / \mathrm{mL} \\
\text { - Genscript } \mathrm{N} \text { protein: } \\
3.03 \mathrm{ng} / \mathrm{mL}\end{array}$ & $20 \mathrm{~min}$ & - & - & - & Half-Strip LFA & [45] \\
\hline 12 & Optical & Colorimetric LFAs & $\begin{array}{l}\text { IgM antibody } \\
\text { IgG antibody }\end{array}$ & Positive and negative & - & $>15 \mathrm{~min}$ & Plasma & $\begin{array}{l}50.8 \\
87.3\end{array}$ & $\begin{array}{l}80 \\
100\end{array}$ & $\begin{array}{l}\text { Clungene }^{\circledR} \\
\text { SARS-CoV-2 }\end{array}$ & [46] \\
\hline 13 & Optical & Colorimetric LFAs & IgG antibody & Positive and negative & - & $15 \mathrm{~min}$ & $\begin{array}{l}\text { Serum, plasma, } \\
\text { or whole blood }\end{array}$ & $\begin{array}{l}95 \\
91 \\
95 \\
92\end{array}$ & $\begin{array}{l}98 \\
100 \\
98 \\
100\end{array}$ & $\begin{array}{l}\text { BTNX kit 1 } \\
\text { BTNX kit } 2 \\
\text { ACON } \\
\text { Laboratories } \\
\text { SD BIOSENSOR }\end{array}$ & [47] \\
\hline 14 & Optical & Colorimetric LFAs & $\begin{array}{l}\text { SARS-CoV- } \\
2 \text { antibodies }\end{array}$ & Positive and negative & - & - & $\begin{array}{l}\text { Serum } \\
\text { specimens }\end{array}$ & 84.4 & 98.6 & LFIAs kít & [48] \\
\hline 15 & Optical & Colorimetric LFAs & $\begin{array}{l}\text { SARS-CoV-2 } \\
\text { nucleocapsid } \\
\text { antigen }\end{array}$ & Positive and negative & - & $15-30 \mathrm{~min}$. & $\begin{array}{l}\text { Nasopharyngeal } \\
\text { and throat swab }\end{array}$ & 98.33 & 98.73 & $\begin{array}{l}\text { Standard }{ }^{\mathrm{TM}} \mathrm{Q} \\
\text { COVID-19 Ag } \\
\text { kit }\end{array}$ & [49] \\
\hline 16 & Optical & Colorimetric LFAs & $\begin{array}{l}\text { IgM/IgG } \\
\text { antibody }\end{array}$ & Positive and negative & - & $15 \mathrm{~min}$ & $\begin{array}{l}\text { Nasopharyngeal } \\
\text { swab }\end{array}$ & $\begin{array}{l}100 / 100 \\
86.36 / 100 \\
86.36 / 100 \\
100 / 100\end{array}$ & - & $\begin{array}{l}\text { Biotime } \\
\text { Biotechnology } \\
\text { Co } \\
\text { Autobio } \\
\text { Diagnostics Co } \\
\text { ISIA } \\
\text { BIO-Technology } \\
\text { Co } \\
\text { Biolidics tests }\end{array}$ & [50] \\
\hline 17 & Optical & $\begin{array}{l}\text { Electrochemiluminescence } \\
\text { immunoassay (ECLIA) }\end{array}$ & IgG antibody & Positive and negative & - & $18-35 \mathrm{~min}$ & Serum & $\begin{array}{l}92.5 \\
87.5\end{array}$ & $\begin{array}{l}98.8 \\
97.5\end{array}$ & $\begin{array}{l}\text { Elecsys }^{\circledR} \text { Anti- } \\
\text { SARS-CoV-2 } \\
\text { LIAISON }{ }^{\circledR} \\
\text { SARS-CoV-2 } \\
\text { S1/S2 IgG }\end{array}$ & [51] \\
\hline
\end{tabular}


Table 2. Cont.

\begin{tabular}{|c|c|c|c|c|c|c|c|c|c|c|c|}
\hline No. & Type of Sensing & Detection Platform & $\begin{array}{l}\text { Recognition } \\
\text { Element }\end{array}$ & $\begin{array}{l}\text { Detection Range/ } \\
\text { Qualitative }\end{array}$ & $\begin{array}{l}\text { Limit of Detection } \\
\text { (LOD) }\end{array}$ & $\begin{array}{l}\text { Detection } \\
\text { Time }\end{array}$ & $\begin{array}{l}\text { Real Sample or } \\
\text { Specimens }\end{array}$ & $\begin{array}{c}\text { Analytical/Clinical } \\
\text { Sensitivity } \%\end{array}$ & $\begin{array}{c}\text { Analytical/Clinical } \\
\text { Specificity \% }\end{array}$ & $\begin{array}{c}\text { Device/ } \\
\text { Commercial } \\
\text { Product }\end{array}$ & Ref. \\
\hline 18 & Optical & $\begin{array}{l}\text { Colorimetric/ } \\
\text { chemiluminescent } \\
\text { LFAs }\end{array}$ & IgA antibody & Positive and negative & - & $15 \mathrm{~min}$ & Serum, saliva & - & - & - & [52] \\
\hline 19 & Optical & Colorimetric LFAs & $\begin{array}{l}\text { SARS-CoV-2 } \\
\text { antigen }\end{array}$ & Positive and negative & $1.7 \times 10^{5}$ copies $/ \mathrm{mL}$ & $15 \mathrm{~min}$ & $\begin{array}{l}\text { Nasopharyngeal } \\
\text { swab }\end{array}$ & 30.2 & 100 & $\begin{array}{l}\text { Coris COVID-19 } \\
\text { Ag Respi-Strip } \\
\text { test }\end{array}$ & [53] \\
\hline 20 & Optical & ELISA & $\begin{array}{l}\text { Neutralizing } \\
\text { antibody }\end{array}$ & Positive and negative & - & - & Blood & - & - & - & [54] \\
\hline 22 & Optical & $\begin{array}{l}\text { Plasmonic } \\
\text { photothermal biosensor }\end{array}$ & RNA & $0.01 \mathrm{pM}$ to $50 \mu \mathrm{M}$ & $0.22 \mathrm{pM}$ & - & - & - & - & - & [56] \\
\hline 23 & NAA-optical & $\begin{array}{l}\text { DNA nanoscaffold- } \\
\text { fluorescent } \\
\text { sensor }\end{array}$ & RNA & $0-100 \mathrm{nM}$ & $0.96 \mathrm{pM}$ & $10 \mathrm{~min}$ & - & - & - & - & [57] \\
\hline 25 & Optical & Nanoplasmonic sensor & $\begin{array}{l}\text { SARS-CoV-2 } \\
\text { virus }\end{array}$ & $10^{2}-10^{7} \mathrm{vp} / \mathrm{mL}$ & $370 \mathrm{vp} / \mathrm{mL}$ & $15 \mathrm{~min}$ & - & - & - & - & [59] \\
\hline 26 & Optical & $\begin{array}{l}\text { Plasmon-enhanced } \\
\text { biosensor }\end{array}$ & $\operatorname{IgM} / \operatorname{IgG} / \operatorname{IgA}$ & Positive and negative & - & $30 \mathrm{~min}$ & $\begin{array}{l}\text { Serum, direct } \\
\text { blood }\end{array}$ & 86.7 & 100 & - & [60] \\
\hline 27 & Electrical & $\begin{array}{l}\text { Field-Effect Transistor } \\
\text { (FET) }\end{array}$ & $\begin{array}{l}\text { SARS-CoV- } \\
2 \text { spike protein } \\
\text { SARS-CoV- } \\
2 \text { virus }\end{array}$ & $\begin{array}{l}100 \mathrm{fg} / \mathrm{mL}-100 \\
\mathrm{pg} / \mathrm{mL} \\
-10^{1}-10^{5} \text { copies } / \mathrm{mL}\end{array}$ & $\begin{array}{l}100 \mathrm{fg} / \mathrm{mL} \\
2.42 \times 10^{2} \\
\text { copies } / \mathrm{mL}\end{array}$ & $>1 \mathrm{~min}$ & $\begin{array}{l}\text { Nasopharyngeal } \\
\text { swab }\end{array}$ & - & - & - & [61] \\
\hline
\end{tabular}


Table 2. Cont.

\begin{tabular}{|c|c|c|c|c|c|c|c|c|c|c|c|}
\hline No. & Type of Sensing & $\begin{array}{l}\text { Detection } \\
\text { Platform }\end{array}$ & $\begin{array}{l}\text { Recognition } \\
\text { Element }\end{array}$ & $\begin{array}{l}\text { Detection Range/ } \\
\text { Qualitative }\end{array}$ & $\begin{array}{l}\text { Limit of Detection } \\
\text { (LOD) }\end{array}$ & Detection Time & $\begin{array}{l}\text { Real Sample or } \\
\text { Specimens }\end{array}$ & $\begin{array}{l}\text { Analytical/Clinical } \\
\text { Sensitivity \% }\end{array}$ & $\begin{array}{l}\text { Analytical/Clinical } \\
\text { Specificity \% }\end{array}$ & $\begin{array}{c}\text { Device/ } \\
\text { Commercial } \\
\text { Product }\end{array}$ & Ref. \\
\hline 28 & $\begin{array}{l}\text { Lab-in-a Tube } \\
\text { Optical }\end{array}$ & $\begin{array}{l}\text { Column } \\
\text { agglutination } \\
\text { test (CAT) } \\
\text { technology }\end{array}$ & Antibodies & Positive and negative & - & $10-30 \mathrm{~min}$ & $\begin{array}{l}\text { Serum } \\
\text { specimens }\end{array}$ & - & - & - & [62] \\
\hline 29 & $\begin{array}{l}\text { Lab-on-a Chip } \\
\text { Optical }\end{array}$ & $\begin{array}{l}\text { Microfluidic } \\
\text { fluorescent } \\
\text { sensor }\end{array}$ & IgG/IgM/Antigen & Positive and negative & - & $15 \mathrm{~min}$ & Serum & - & - & - & [63] \\
\hline 30 & Electrochemical & Amperometry & S-RBD protein & $0-1400 \mathrm{nM}$ & - & $30 \mathrm{~s}$ & $\begin{array}{l}\text { Nasal secretions } \\
\text { and saliva }\end{array}$ & - & - & - & [64] \\
\hline 31 & Electrochemical & Impedance & $\begin{array}{l}\text { Antibodies to } \\
\text { SARS-CoV-2 S1 } \\
\text { protein } \\
\text { Receptor- } \\
\text { binding-domain } \\
\text { (RBD) }\end{array}$ & $\begin{array}{l}1 \mathrm{fM}-20 \mathrm{nM} \\
1 \mathrm{fM}-20 \mathrm{nM}\end{array}$ & $\begin{array}{l}2.8 \times 10^{-15} \mathrm{M} \\
16.9 \times 10^{-15} \mathrm{M}\end{array}$ & $10 \mathrm{~s}$ & Serum & - & - & - & [65] \\
\hline 32 & Electrochemical & Impedance & $\begin{array}{l}\text { CR3022 } \\
\text { Antibody }\end{array}$ & $0.1-10 \mu \mathrm{g} / \mathrm{mL}$ & - & $5 \min$ & Serum & - & - & - & [66] \\
\hline 33 & Electrochemical & Amperometry & RNA & $\begin{array}{l}585.4-5.854 \times 10^{7} \\
\text { copies } / \mu \mathrm{L}\end{array}$ & 6.9 copies $/ \mu \mathrm{L}$ & $<5 \mathrm{~min}$ & $\begin{array}{l}\text { Nasopharyngeal } \\
\text { swab, saliva }\end{array}$ & - & - & - & [67] \\
\hline
\end{tabular}




\subsection{Nucleic Acid Amplification-Based Techniques as Gold Standard Diagnostic Tests}

A variety of NAA techniques have been incorporated into well-known clinical diagnostic tests, such as polymerase chain reaction (PCR), real-time PCR, and reverse transcriptionmediated isothermal amplification (RT-LAMP). These techniques have widespread research applications in the diagnosis of COVID-19 as the gold standard diagnosis at the start of a pandemic. These techniques are well-developed owing to their simplicity, sensitivity, and speed. Chu et al. 2020 developed a one-step quantitative real-time RT-PCR in addition to a biological sensor for monitoring two different regions (ORF1b and ORFN) of the SARSCoV-2 viral genome. Instead of two-step RT-PCR that separately conducts RNA reverse transcription and amplification steps, reverse transcriptase and DNA polymerase enzymes were premixed in a single tube that allows both steps to be performed in single reaction. These NAA-based sensors excel in the analytical requirements but are typically limited due to their time-consuming processes. RT-PCR platform has a lengthy laboratory workflow requiring multiple solution operation steps and relies on sophisticated equipment for thermal cycling and optical signal detection. It may not be a viable option for the screening of COVID-19 at locations where laboratories and highly trained technicians are absent. The aim of one-step quantitative RT-PCR is the rapid detection of SARS-CoV-2 in human samples (75 min), which is highly acceptable in clinical tests, however, it is more cost-effective, and required a robust manner in laboratories in different geographical regions. This twostage amplification closed-tube diagnostic assay was used to test SARS-CoV-2 samples with significantly enhanced sensitivity compared to conventional RT-PCR with dynamic range of at least seven orders of magnitude $\left(2 \times 10^{-4}-2000 \mathrm{TCID}_{50} /\right.$ reaction $)$ for RNA from SARS infected cells and below 10 copies per reaction for DNA plasmid as positive standards [38]. Chow et al. 2020 demonstrated the potential of the LAMP-based sensor of SARS-CoV-2 by monitoring the color change of the different concentrations of clinical samples which was detectable by naked eye [40]. This method was designed to directly amplify the target through one-step RT-LAMP test, then target RNA was confirmed via colorimetric method that showed the efficiency of detection of target RNA genome within range of 45-105 min including sample extraction time, depending on viral load. The tested clinical samples, which were different in nature (respiratory samples, nasopharyngeal swabs, sputum/deep throat saliva, and throat swabs), were confirmed by RT-PCR and collected at different reaction times (60 min and $90 \mathrm{~min}$ ). Interestingly, the test with nasopharyngeal swab samples showed the highest sensitivity, with $96.88 \%$ (95\% CI: $0.93-1.00)$ and $98.96 \%$ (95\% CI: 0.97-1.00) of 96 samples positive by RT-LAMP at 60 and $90 \mathrm{~min}$, respectively. In addition, the other clinical samples had high sensitivity of at least $93.33 \%(0.87-1.00)$, suggesting that this platform exhibits high potential in the detection application of SARS-CoV-2. In addition, Viet Loan et al. 2020 investigated key issues related to the colorimetric RT-LAMP assay and LAMP-sequencing, sensor characteristics, sensitivity and specificity in detecting SARS-CoV-2 RNA both in vitro and in vivo. The inclusion of RT-LAMP and colorimetric methods in the matrix increased the simple, scalable, and broadly applicable testing methods of the sensor. Furthermore, the sensor characteristics of the colorimetric RT-LAMP assay were tested on 768 pharyngeal swab specimens using a primer set specific for the $\mathrm{N}$ gene and compared an RT-PCR assay using a sensitive primer set with a sensitivity of $97.5 \%$ and specificity of $99.7 \%$. In particular, the swab-to-RT-LAMP assay without a prior RNA isolation step showed excellent specificity $(99.5 \%)$ but lower sensitivity $(86 \%$ for CT <30) than the RT-LAMP assay [41] (Figure 2). Furthermore, Ackerman et al. 2020 developed combinatorial arrayed reactions for multiplexed evaluation of nucleic acids (CARMEN) for the evaluation of multiplex pathogenic nucleic acids to detect pathogens. CRISPR-based nucleic acid detection reagents containing in nanoliter droplets could self-organize in arrays to pair with droplets of amplifies samples, testing samples against CRISPR RNA (crRNA) in replicate. With the combination of CARMEN and Cas13 detection, the assay simultaneously differentiated 169 human-related viruses and incorporated an additional crRNA to detect target of COVID-19. The CARMEN assay enables the scalability, miniaturization, and cost-effectiveness, shifting diagnostic ability from targeted high-priority samples to 
comprehensive large samples [69]. Traditional NAA technique is time-consuming and may have false-positive outputs based on the working experience of the technician with careful consideration throughout the testing time. However, PCR has become an indispensable and integral part of clinical and diagnostic research as the gold standard in hospitals due to their unique performance. One of the significant applications of the NAA-based techniques was their utility in the confirmation of SARS-CoV-2 infection for the better intervention of COVID-19 pandemic, which can shift diagnostic and surveillance efforts from targeted testing of high-priority samples to comprehensive testing of large sample sets, bringing great benefits to patients and public health.

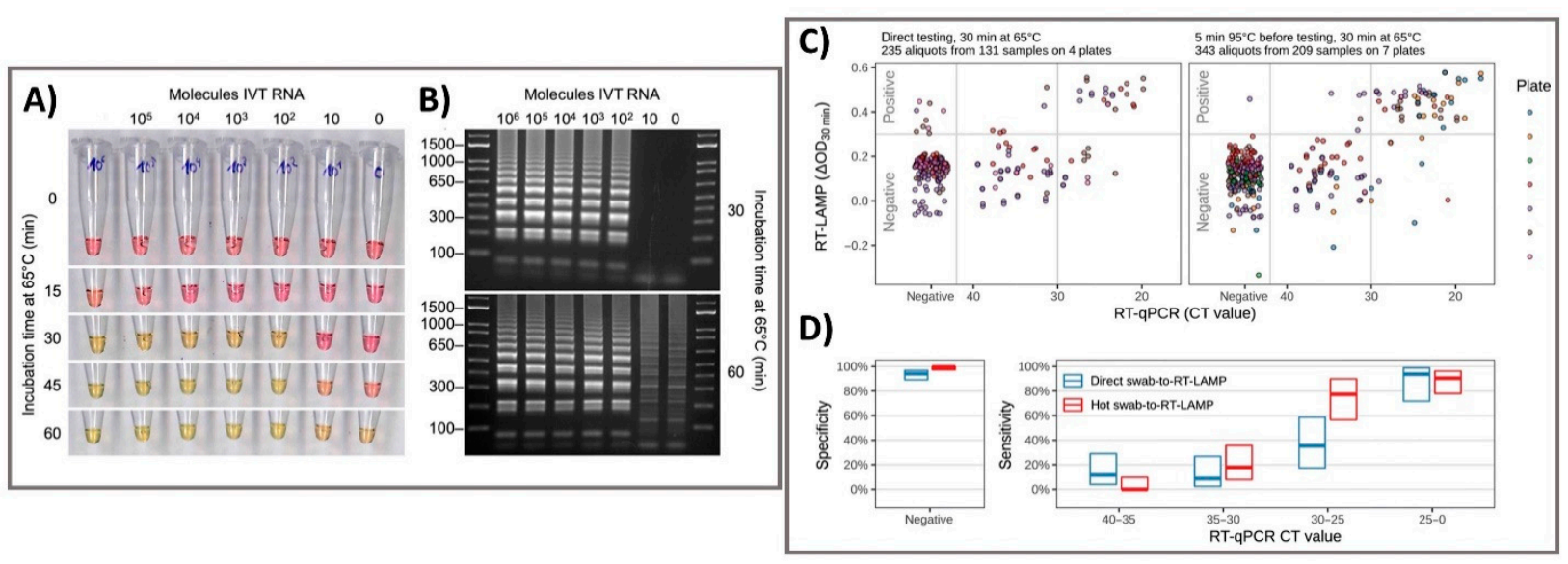

Figure 2. Colorimetric RT-LAMP and LAMP sequencing for the clinical detection of SARS-CoV-2 RNA. (A) The oligonucleotide set for the nucleocapsid (N) gene of SARS-CoV-2 was added to the RT-LAMP reaction and incubated at $65{ }^{\circ} \mathrm{C}$. The colors of samples changed from red-to-yellow and the negative control was yellowish. (B) Gel electrophoresis showed RT-LAMP reaction products with distinct banding patterns. (C) For clinical pharyngeal swab samples, the direct swab-toRT-LAMP assay measurements or after 5 min of heat treatment at $95^{\circ} \mathrm{C}$ were compared for their $\Delta \mathrm{OD}$ values from the swab-to-RT-LAMP assay and CT values from the RT-qPCR assay. (D) The sensitivity and specificity of the swab-to-RT-LAMP assay were revealed with their $95 \%$ confidence intervals, with the direct swab-to-RT-LAMP assay (blue color) and the heated swab-to-RT-LAMP assay (red color). Reprinted with permission from [41]. Sci. Transl. Med. 2020, 12, 556, eabc7075. Copyright 2020, American Association for the Advancement of Science.

\subsection{Optical Sensing Platforms as Rapid Point-Of-Care Screening Tests}

Optical biosensors are one of the most common platforms that have been exploited to monitor various target for clinical diagnostics. They detect biological interactions by evaluating induced variations in the properties of light, such as intensity, wavelength, index of refraction, or polarization. Cutting-edge optical sensing platform technologies are currently being investigated for COVID-19 clinical samples, including samples based on lateral flow assays (LFAs), enzyme-linked immunosorbent assay (ELISA), chemiluminescent immunoassay, plasmonic biosensor, and localized surface plasmon resonance. Grant et al. 2020 developed half-strip LFAs as useful first step in the development of LFA platforms for the detection of SARS-CoV-2 using commercially available antibodies. This half-strip LFA exhibited high sensitivity toward SARS-CoV-2 with limit of detection (LOD) at $0.65 \mathrm{ng} / \mathrm{mL}$ by visual read or optical reader [45] (Figure 3). LFA is a good biosensing candidate for diagnostic applications owing to their advantages including high sensitivity and specificity, excellent biological compatibility, short duration, stable output, and affordability. More importantly, the LFA holds the potential for large-scale production and commercialization with convenient protocol without technical professions, allowing it to be POC test worldwide for initial screening of SARS-CoV-2 infection. Due to the feasibility of LFA biosensing platforms for the effective detection of SARS-CoV-2 biomarkers, there were several LFA strips developed from different companies. Demey et al. 2020 evaluated the sensing performance to detect SARS-CoV-2 using four immunochromatographic antibody 
assays of different commercial companies. Using SARS-CoV-2 positive samples confirmed by RT-PCR from 22 patients, they demonstrated that the ability of COVID-19 confirmation through antibody using these LFAs was depended on time with the median detection time about 8-10 days since the onset of symptoms, and the sensitivity was increased up to $60-80 \%$ on day 10 and $100 \%$ on day 15 , indicating that these LFA tests were reliable at 14-15 days post-infection [50]. The low-cost LFA combined with an easily accessible synthetic biosensor that can function with bodily fluids as samples provides a comprehensive solution for the diagnosis of non-communicable diseases in resource-limited developing countries [70]. Instead of LFAs, the use of dual-functional plasmonic biosensor by combining plasmonic photothermal and localized surface plasmon resonance sensing transduction could provide a promising alternative optical biosensor. Qiu et al. 2020 identified an optical LOD of approximately $0.22 \mathrm{pM}$ and confirmed a detection range of $0.01 \mathrm{pM}$ to $50 \mu \mathrm{M}$ for the detection of target SARS-CoV-2 sequences [56]. The highly sensitivive detection of target sequences was achieved by using 2D gold nanoislands (AuNIs) functionalized with complementary DNA receptors through nucleic acid hybridization. To enhance sensing performance, thermoplasmonic heat was generated on AuNI chip under illuminated at plasmonic resonance frequencies, elevating the in situ hybridization temperature and facilitating the accurate differentiation of two similar gene sequences. This dual-functional plasmonic biosensor exhibited the potential application in nucleic acid tests for viral disease diagnosis. Overall, these types of optical sensing platform enable the detection of SARS-CoV-2 biomarkers for the confirmation of COVID-19 in human samples including serum, plasma, blood, nasopharyngeal, and oropharyngeal swab specimens, with high sensitivity, specificity. With these advantages, the strong capability of translation of the signal intensity into the accurate concentration of biomarkers makes optical platforms important as applicable biosensors for POC diagnostic of COVID-19 in clinical. Therefore, almost clinical tests utilized optical sensing platform have been currently exploited as an effective tool for diagnosis of disease by sensing of biomarkers in human biological specimens. Compared to other optical biosensors that have been developed to detect SARS-CoV-2, it is worth noticing that LFA exhibits the superior potential to serve as diagnostic tools for initial screening of COVID-19 with acceptable results, short-time consumption and reasonable price, suggesting a good choice for developing and underdeveloped countries to utilize LFAs as POC diagnostic tool for managing the COVID-19 pandemic.
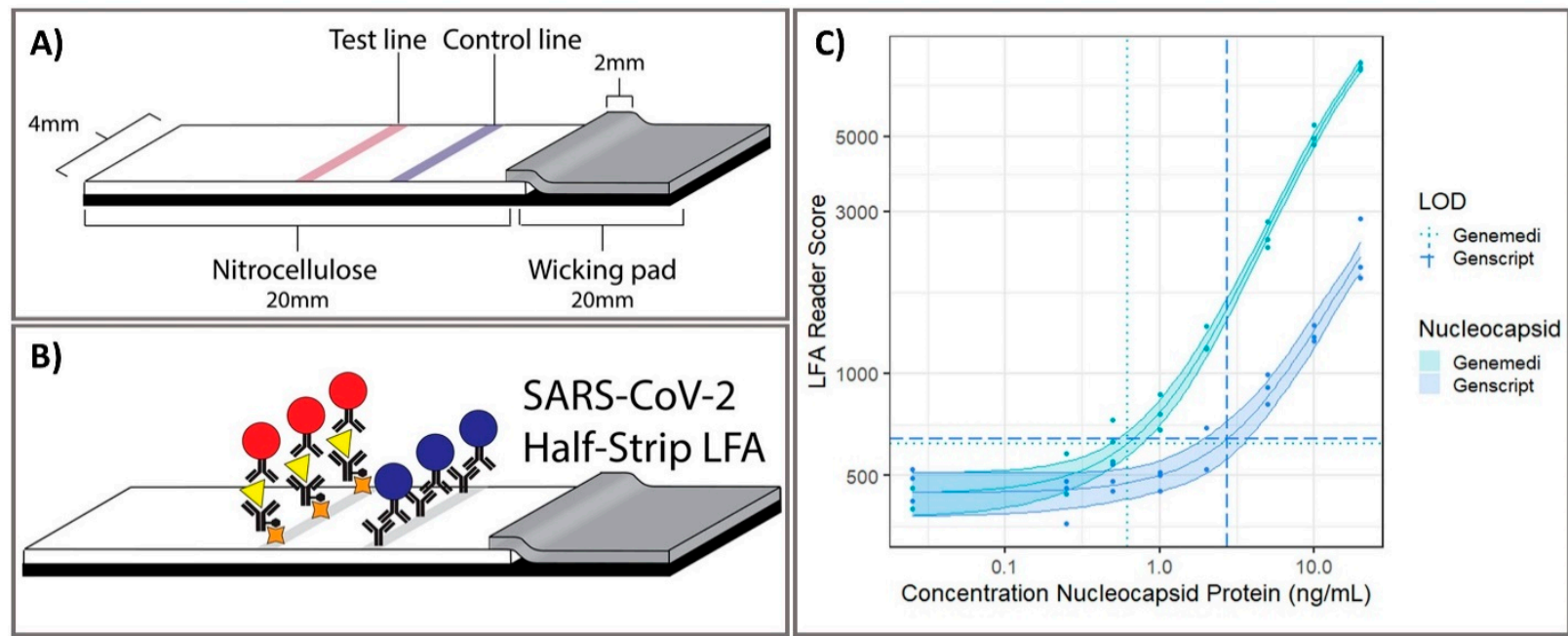

Figure 3. Point-of-care half-strip lateral flow assay for the detection of the nucleocapsid antigen of SARS-CoV-2. (A) The $4 \mathrm{~mm}$ width half-strip was constructed using a $20 \mathrm{~mm}$ nitrocellulose analytical membrane, $20 \mathrm{~mm}$ wicking pad by using a Kinematic Matrix guillotine cutter. (B) LFA was treated in buffer and color intensity of test zone was differentiated after $20 \mathrm{~min}$. (C) The dosage response curve for half-band LFA using nucleocapsid proteins from two commercially available sources, measured with commercially available optical LFA readers. Reprinted with permission from [45]. Anal. Chem. 2020, 92, 16, 11305-11309. Copyright 2020, American Chemical Society. 


\subsection{Lab-In-A-Tube and Electrochemical Sensors as Emerging Ultrasensitive Real-Time Monitors}

Laboratory diagnostics which compatible with critical laboratory equipment are conceptually easily applied to patients, given the features of the following multiple operations of virus testing [71]. Exposure tracking can limit the viral spread, however, population screening to determine virus infection levels in the community is a longer-term need. For lab-in-a-tube, Alves et al. 2020 built a sensing platform using gel tag agglutination tests to target SARS-CoV-2 with rapid case identification (Figure 4). Ten serological samples in both gel cards and indirect IgG ELISA were tested and showed that similar performance between them, suggesting this assay as one of suitable approach for clinical diagnosis compared to conventional ELISA, owing to its advantages in excellent resolution and benefits of high throughput, high speed (10-30 min), automatic in most cases, and possibility for POC diagnostics. From gel card agglutination assays to lab-in-a-tube systems, this simple, rapid, and scalable approach could identify disease-specific activity to apply in SARS-CoV-2 testing, suggesting the ability to move diagnostics to the POC test for COVID-19 confirmation [62]. In addition, Lin et al. 2020 recently demonstrated real-time and continuous monitoring platform using integrated diagnostic microchips, homemade mobile fluorescence detectors, and microfluidic immunoassay systems for the simultaneous detection of IgG/IgM/antigen in SARS-CoV-2. This system was utilized for SARS-CoV-2 serological testing, displaying high accuracy not only in distinguishing between infected and uninfected cases but also in determining the severity the disease, allowing disease staging as follows: stage 1 (infected 1-7 days), stage 2 (infected 8-14 days), and stage 3 (infected over 14 days). Furthermore, this system showed excellent sensor characteristics with a rapid response time of $15 \mathrm{~min}$ [63]. For case of electrochemical sensor, Vadlamani et al. 2020 designed an electrode composed of cobalt-functional $\mathrm{TiO}_{2}$ nanotubes (Co-TNT) as electrochemical sensor for the rapid detection of SARS-CoV-2 at low concentration range from 14-1400 $\mathrm{nM}$ with LOD of $\sim 0.7 \mathrm{nM}$. The authors then used this system for real-time concentration measurements, showing a linear response in detecting viral proteins within concentration range for approximately $30 \mathrm{~s}$ in saliva and nasal secretions. The sensitivity of this approach can also be improved by using longer Co-TNTs due to higher surface area results in higher response rates, thus higher electric current can be obtained even at lower protein concentrations [64]. Furthermore, an advanced nanomaterial-based electrochemical biosensor to detect SARS-CoV-2 antibodies within seconds was successfully developed to enhance the rapid diagnosis of COVID-19 for the better treatment and prevention of diseases [65]. The three-dimensional (3D) electrodes were printed using 3D nanoprinting and were coated with nanoflakes of reduced-graphene-oxide (rGO); specific viral antigens were then immobilized on the rGO nanoflakes. The electrode was then integrated with a microfluidic device and applied as an electrical immunosensor. In the presence of antibodies against the SARS-CoV-2 S1 protein, the antibodies selectively bound to the antigens due to their strong immunoaffinity, leading to a change in impedance of the electrical circuit, which is detected via impedance spectroscopy. Antibodies to SARS-CoV-2 S1 protein and its receptor-binding domain were detected by a smartphone-based user interface within $10 \mathrm{~s}$ with a wide concentration range from $1 \mathrm{fM}$ to $20 \mathrm{nM}$ at LOD of $2.8 \times 10^{-15}$ and $16.9 \times 10^{-15} \mathrm{M}$, respectively (Figure 5). Seo et al. 2020 developed the field-effect transistor based biosensing device with the support of antibody functionalized graphene sheets to detect SARS-CoV-2 protein in human nasopharyngeal swab specimens. This platform helped improve nano-sensor performance in clinical samples for over $1 \mathrm{~min}$ without significantly altering the sensing capacity to detect SARS-CoV-2 without requiring sample pretreatment or labeling. This device showed good sensitivity for the detection of SARS-CoV-2 spike protein at the concentration of $1 \mathrm{fg} / \mathrm{mL}$ in phosphate-buffered saline and $100 \mathrm{fg} / \mathrm{mL}$ in clinical transport medium. Moreover, the device could detect SARSCoV-2 in the culture medium with LOD of $1.6 \times 10 \mathrm{pfu} / \mathrm{mL}$ and clinical samples with LOD of $2.42 \times 10^{2}$ copies $/ \mathrm{mL}$, respectively. This fully reversible modular sensing platform is a viable candidate for continuous clinical monitoring [61]. Overall, these biosensing platforms mentioned above exhibits high sensitivity, selectivity, and the rapid ability of 
monitoring SARS-CoV-2 for application in diagnosis of COVID-19. However, it highly requires the technical professions and instruments to conduct the sensing process that could ensure the accurate diagnosis. The important mission for researchers is to achieve proper stability, remove unwanted noise, and make the products commercially applicable after conducting a successful clinical trial.
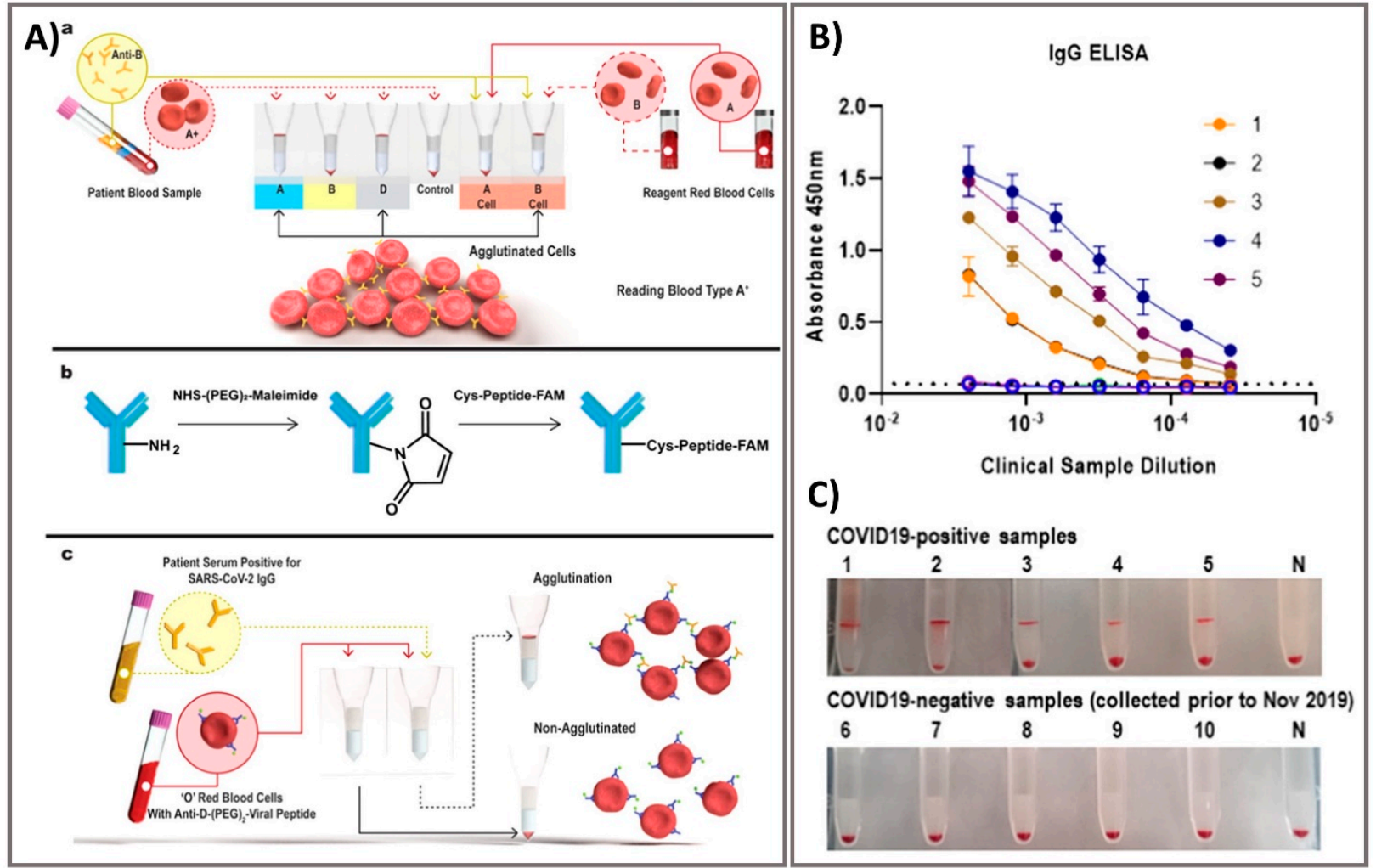

Figure 4. Rapid agglutination assays as serological testing for the detection of antibodies against SARS-CoV-2. (A) Schematic illustration of blood typing column agglutination test (CAT) with the brief antibody-peptide bioconjugates to produce the SARS-CoV-2 serological assay. (a) Pipette a mixture of reagent red blood cells (RRBCs) with patient samples onto a gel card containing separation media, followed by incubation of the card for 5-15 $\mathrm{min}$. (b) The bioconjugation procedure to produce the antibody-peptide in two steps. (c) Antibody-peptide-coated RRBCs were incubated with a patient sample on a neutral gel prior to centrifugation to separate agglutinated RRBCs from free RRBCs for visual examination. Following optimization of the gel card assays to distinguish between SARS-CoV-2-positive samples and negative controls, 10 clinical samples were tested in both gel cards and by indirect IgG ELISA. (B) The results of indirect IgG ELISA comparing 10 samples, including PCR-confirmed SARS-CoV-2-positive samples and samples from healthy individuals collected before the SARS-CoV-2 outbreak. (C) Digital images of gel card assays recorded from experiments could identify positive/negative of antibodies, negative control noted ("N"). Reprinted with permission from [62]. ACS Sens. 2020, 5, 8, 2596-2603. Copyright 2020, American Chemical Society. 


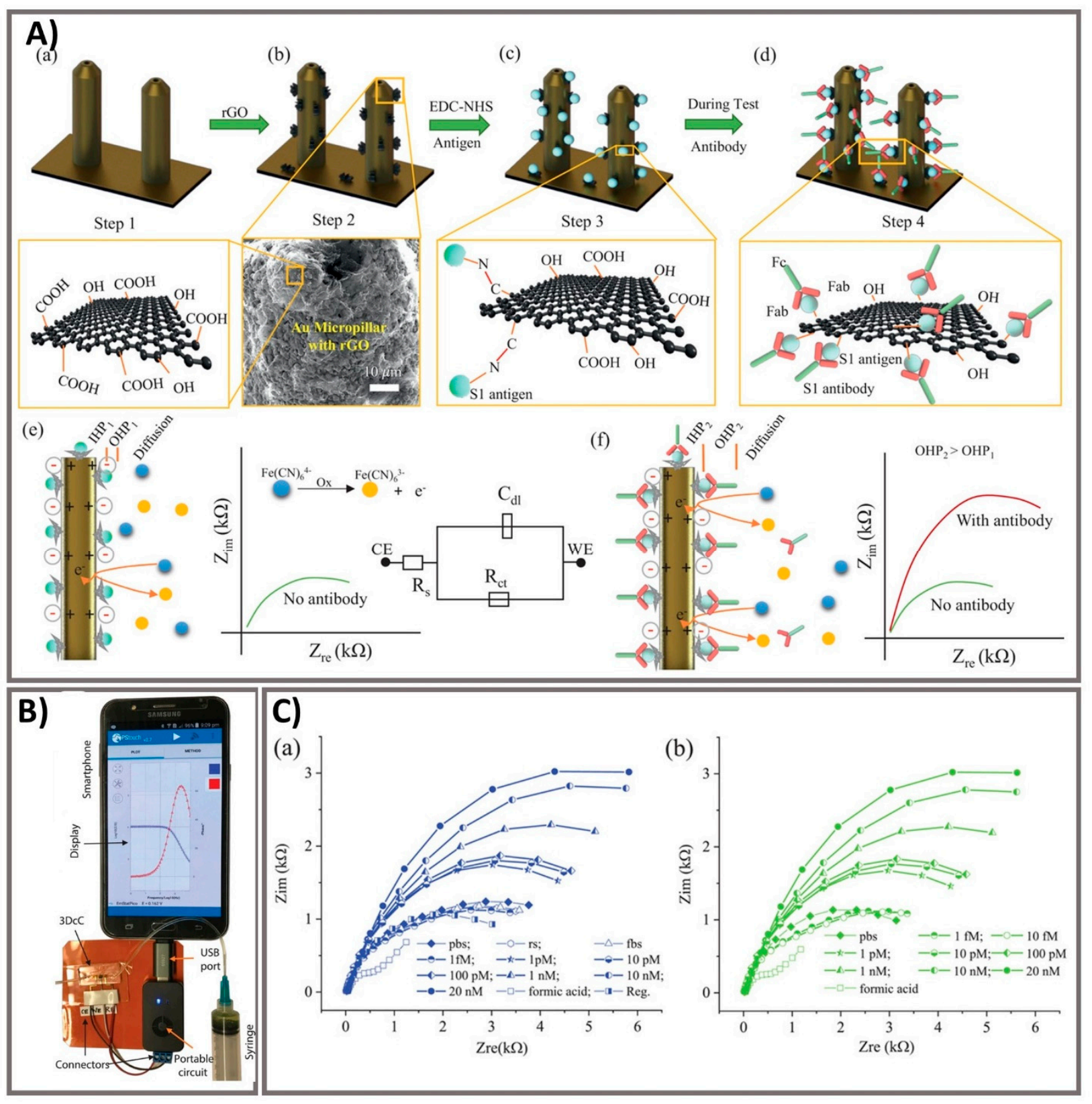

Figure 5. Ultra-rapid electrochemical immunosensor using aerosol jet nanoprinted reduced graphene oxide-coated 3D electrode for the detection of antibodies against SARS-CoV-2. (A) Functionalization of the 3D electrode and sensing operation. (a) AJ-printed gold micropillars prior to the surface treatment. (b) Coating rGO sheets onto the electrodes. (c) Immobilization of viral antigens onto rGO sheets. (d) Selective binding of antibody with specific antigens after introduction. (e) Schematics showing the sensing principle of the 3DcC device. (f) Schematic illustration of the Nyquist plot alternation via electrical impedance spectroscopy (EIS) before and after antibody introduction and binding with the antigens on the electrode surface. (B) The connection of the 3DcC device interfaced with a portable potentiostat to a smartphone via a USB-C connection for signal recording. (C) Sensing performance of antibodies against SARS-CoV-2 spike S1 antigen at different molar concentrations from $1 \mathrm{fM}$ to $20 \mathrm{nM}$ in (a) PBS solution and (b) after sensor regeneration using low-pH chemistry. Reprinted with permission from [65].

\section{Concluding Remarks and Perspectives}

The recent global COVID-19 outbreak has killed more than 1,669,982 people (as of 19 December 2020) and has strongly affected the global economy, causing economic hardship for millions of people worldwide [72]. The rapid spread of SARS-CoV-2 with many fatal cases is currently considered as global concern. Extensive progress has been making in 
understanding the virology of SARS-CoV-2 as well as the benefit and drawback of various detection techniques for COVID-19, and the reasons behind the widespread human-tohuman transmission of SARS-CoV-2. In addition, there are many other factors contributing to the infectious and pathogenic potential of SARS-CoV-2 that need to be investigated. It is worth noticing that molecular diagnostic tools are crucial for clinical diagnosis, public health monitoring, and mitigation strategies to prevent the spread of COVID-19. Specifically, rapid, simple, affordable, and reliable sensor platforms are currently in demand, especially as the disease spreads across low- and middle-income countries. Even though many emerging platforms have been successfully developed for the accurate diagnosis of COVID-19, including LFAs, plasmonic biosensor, electrochemical sensors, or lab-in-a-chip with the support of nanomaterials, these are not efficient alternatives to RT-PCR technique which is still considered as gold standard diagnostic for confirming the SARS-CoV-2 infection. Table 3 summarizes the advantages and disadvantages of different sensing platforms for detection of SARS-CoV-2, suggesting the possibility of each platform for COVID-19 diagnosis, particularly, LFAs as screening test, NAA-based techniques as confirmatory test, and optical or electrochemical biosensors as tracking test of infection stages and treatment response. Hence, the combination of the different diagnostic techniques could improve the accuracy of COVID-19 detection, significantly improving the effectiveness of diagnosis and treatment. Further advances in analytical technologies through a multidisciplinary approach will strongly associate with the development of therapeutic and vaccine strategies to fight COVID-19 pandemic. Before vaccines are widely approved for clinical use, there was no better way to prevent SARS-CoV-2 infection than through diagnostic tools to monitor public health, and personal preventive behaviors, such as social distancing and masks. For future studies, it is important to continue monitoring the SARS-CoV-2 genome in new cases worldwide to promptly identify any mutations that could lead to changes in the phenotype of the virus. The accurate biosensors have been developed and utilized in clinical diagnosis of COVID-19 after clinical trials, effectively contributing to the better intervention of SARS-CoV-2 pandemic. Thus, the lessons discovered from the COVID-19 molecular diagnostics are valuable for providing a better response to other future diseases. Finally, COVID-19 pandemic is a challenge for all humankind and the management of this pandemic is a permanent undertaking, requiring the efforts of each individual and the international cooperation of scientists, governments, and the public. The satisfactory utilization of advanced diagnostic tools for COVID-19 exhibits the great significance to overcome this pandemic, acquiring the thorough preparation and valuable experiences to win over any future pandemic. 
Table 3. The advantages and disadvantages of different sensing platforms for SARS-CoV-2 detection.

\begin{tabular}{|c|c|c|c|c|}
\hline No. & Platforms/Per-Test Cost & Principle & Advantages & Disadvantages \\
\hline \multirow[t]{2}{*}{1} & $\begin{array}{l}\text { Nucleic acid amplification } \\
\text { RT-PCR } \\
\text { ( 50-150 dollars) }\end{array}$ & $\begin{array}{l}\text { Under different temperatures, } \\
\text { utilization of a specific set of primers, } \\
\text { nucleotides, reverse transcriptase } \\
\text { enzyme and DNA polymerase enzyme } \\
\text { for reverse transription of RNA into } \\
\text { complementary DNA and amplification } \\
\text { of cDNA to detect specific target RNA } \\
\text { sequence. }\end{array}$ & $\begin{array}{l}\text { - Fairly quick and fewer false-negative results } \\
\text { - Higher sensitivity and reliability } \\
\text { - Able to follow social distancing when clinical } \\
\text { samples are taken from the suspected infected } \\
\text { patient's car or at home. } \\
\text { - RT-PCR products are widely available for the } \\
\text { detection of clinical samples by medical staff in } \\
\text { hospitals or scientists and technicians in } \\
\text { laboratories. }\end{array}$ & $\begin{array}{l}\text { - Incapable of completing the detection process } \\
\text { in a short time ( } 3-4 \mathrm{~h}) \\
\text { - Possible to miss corona positive patient who } \\
\text { has virus clearance and recovered from disease } \\
\text { due to the ability of detection based on } \\
\text { capturing and detecting virus. } \\
\text { - Costly lab equipment and experimental } \\
\text { materials. } \\
\text { - Complex detection process but not provide } \\
\text { more information about other diseases or } \\
\text { symptoms. }\end{array}$ \\
\hline & $\begin{array}{l}\text { RT-LAMP } \\
(\sim 50-150 \text { dollars })\end{array}$ & $\begin{array}{l}\text { Under isothermal conditions, the } \\
\text { utilization of at least two specific sets of } \\
\text { primers, nucleotides, reverse } \\
\text { transcriptase enzyme and DNA } \\
\text { polymerase enzyme for RNA reverse } \\
\text { transription and cDNA amplification to } \\
\text { detect specific target RNA sequence }\end{array}$ & $\begin{array}{l}\text { - LAMP is more quickly technique that can get } \\
\text { results within } 1-3 \mathrm{~h} \text {. } \\
\text { - Has a single temperature }\left(60-65^{\circ} \mathrm{C}\right) \text { with no } \\
\text { specific skills required. } \\
\text { - Purification steps are not necessarily based on } \\
\text { the stable reaction and inhibitors are tolerated, } \\
\text { and results can be recorded with naked eye. } \\
\text { - This smaller, simpler, portable method can be } \\
\text { performed within hospital laboratories. }\end{array}$ & $\begin{array}{l}\text { - Newer technique that is still being evaluated } \\
\text { in clinical. } \\
\text { - Too sensitive and susceptible to false positive } \\
\text { because of cross-contamination. } \\
\text { - Possible to miss corona positive patient who } \\
\text { has virus clearance and recovered from disease } \\
\text { due to the ability of detection based on } \\
\text { capturing and detecting virus. } \\
\text { - Not provide more information about other } \\
\text { diseases or symptoms. }\end{array}$ \\
\hline
\end{tabular}


Table 3. Cont.

\begin{tabular}{|c|c|c|c|c|}
\hline No. & Platforms/Per-Test Cost & Principle & Advantages & Disadvantages \\
\hline \multirow[t]{2}{*}{2} & $\begin{array}{l}\text { Optical sensing } \\
\text { Lateral flow assays } \\
(\sim 2-10 \text { dollars })\end{array}$ & $\begin{array}{l}\text { Liquid samples, including target } \\
\text { analyte, move without external force } \\
\text { through different test trips where } \\
\text { molecules that can react to target } \\
\text { analyte are captured, resulting in } \\
\text { optical signal. }\end{array}$ & $\begin{array}{l}\text { - Remarkably fast for a POC test with final } \\
\text { results obtained at approximately less than } 30 \\
\text { min. } \\
\text { - No need for experts to perform clinical tests, } \\
\text { no specialist laboratories or instruments } \\
\text { required. } \\
\text { - Non-invasive test for the presence of } \\
\text { SARS-CoV-2. }\end{array}$ & $\begin{array}{l}\text { - Cannot quantitate the clinical samples. } \\
\text { - Intensive experiment to produce antibody } \\
\text { - Insufficient evidence for effectiveness and } \\
\text { accuracy in SARS-CoV-2 diagnosis is still being } \\
\text { evaluated. } \\
\text { - Further test should be checked to confirm }\end{array}$ \\
\hline & $\begin{array}{l}\text { Enzyme-linked immunosorbent assay } \\
\text { ( } 30-70 \text { dollars })\end{array}$ & $\begin{array}{l}\text { Different antigen-antibody } \\
\text { combinations are used, which always } \\
\text { include an enzyme-labeled antibody or } \\
\text { antigen, and the enzyme activity is } \\
\text { measured by optical techniques that } \\
\text { collerates with target concentrations. }\end{array}$ & $\begin{array}{l}\text { - Highly sensitive, straightforward, and cheap } \\
\text { laboratory technique } \\
\text { - High throughput can analyze multiple } \\
\text { samples from different patients within 2-4h. } \\
\text { - High-level technicians are not required. } \\
\text { - Possibility of quantitating samples. } \\
\text { - Well established in hospital }\end{array}$ & $\begin{array}{l}\text { - Not yet well-acknowledged as a standard for } \\
\text { SARS-CoV-2 detection. } \\
\text { - Intensive experiment to produce antibody. } \\
\text { - High probalibity of false positive/negative } \\
\text { results } \\
\text { - Temporary read-out results in a short } \\
\text { timeframe due to the enzyme/substrate } \\
\text { reactions. }\end{array}$ \\
\hline 3 & $\begin{array}{l}\text { Electrochemical sensing } \\
\text { (not yet commercialized products) }\end{array}$ & $\begin{array}{l}\text { Due to bio/chemical reaction, the } \\
\text { change of bio/chemical signal can } \\
\text { translate into electrical signal that } \\
\text { collerates with the concentration of } \\
\text { target. }\end{array}$ & $\begin{array}{l}\text { - Only a small amount of material is needed. } \\
\text { - Simplicity, high sensitivity, consistency, } \\
\text { selectivity, and reproducibility. } \\
\text { - Provide a faster, real-time detection of target. } \\
\text { - Possibility of continuous analysis. } \\
\text { - Excellent repeatability with high correctness. }\end{array}$ & $\begin{array}{l}\text { - Identification as prototypes and just } \\
\text { evaluation under laboratory conditions so far. } \\
\text { - Difficulty in supplying the commercial } \\
\text { products. } \\
\text { - Narrow or limited temperature range. } \\
\text { - Short or limited shelf life. } \\
\text { - Difficulty in optimizing the stability, storage, } \\
\text { logistics of sensors. }\end{array}$ \\
\hline
\end{tabular}


Author Contributions: Conceptualization, L.M.T.P. and S.C.; methodology, L.M.T.P. and M.-V.T.; validation, L.M.T.P. and S.C.; investigation, L.M.T.P., M.-V.T. and T.-T.P.; writing-original draft preparation, L.M.T.P., M.-V.T. and T.-T.P.; writing-review and editing, L.M.T.P.; supervision, L.M.T.P. and S.C.; project administration, S.C. All authors have read and agreed to the published version of the manuscript.

Funding: This research was supported by the National Research Foundation of Korea (NRF2020M3A9E410438511) and by the GRRC program of Gyeonggi province (GRRC-Gachon2020(B01), AI-based Medical Image Analysis).

Institutional Review Board Statement: Not applicable.

Informed Consent Statement: Not applicable.

Data Availability Statement: Not applicable.

Conflicts of Interest: There is no known competing financial interest.

\section{References}

1. Hossain, M.G.; Javed, A.; Akter, S.; Saha, S. SARS-CoV-2 host diversity: An update of natural infections and experimental evidence. J. Microbiol. Immunol. Infect. 2021, 54, 175-181. [CrossRef] [PubMed]

2. Maganga, G.D.; Pinto, A.; Mombo, I.M.; Madjitobaye, M.; Beyeme, A.M.M.; Boundenga, L.; Gouilh, M.A.; N’Dilimabaka, N.; Drexler, J.F.; Drosten, C.; et al. Genetic diversity and ecology of coronaviruses hosted by cave-dwelling bats in Gabon. Sci. Rep. 2020, 10, 1-13. [CrossRef] [PubMed]

3. Park, J.; Chung, E. Learning from past pandemic governance: Early response and Public-Private Partnerships in testing of COVID-19 in South Korea. World Dev. 2021, 137, 105198. [CrossRef]

4. Zhu, Z.; Lian, X.; Su, X.; Wu, W.; Marraro, G.A.; Zeng, Y. From SARS and MERS to COVID-19: A brief summary and comparison of severe acute respiratory infections caused by three highly pathogenic human coronaviruses. Respir. Res. 2020, $21,1-14$. [CrossRef] [PubMed]

5. da Costa, V.G.; Moreli, M.L.; Saivish, M.V. The emergence of SARS, MERS and novel SARS-2 coronaviruses in the 21st century. Arch. Virol. 2020, 165, 1517-1526. [CrossRef] [PubMed]

6. Hong, G.-L.; Deng, H.-H.; Zhao, H.-L.; Zou, Z.-Y.; Huang, K.-Y.; Peng, H.-P.; Liu, Y.-H.; Chen, W. Gold nanoclusters/graphene quantum dots complex-based dual-emitting ratiometric fluorescence probe for the determination of glucose. J. Pharm. Biomed. Anal. 2020, 189, 113480. [CrossRef]

7. Zheng, J. SARS-CoV-2: An Emerging Coronavirus that Causes a Global Threat. Int. J. Biol. Sci. 2020, 16, 1678-1685. [CrossRef]

8. Rudan, I. A cascade of causes that led to the COVID-19 tragedy in Italy and in other European Union countries. J. Glob. Health 2020, 10, 010335. [CrossRef]

9. Choi, J.Y. COVID-19 in South Korea. Postgrad. Med. J. 2020, 96, 399-402. [CrossRef]

10. Bherwani, H.; Gupta, A.; Anjum, S.; Anshul, A.; Kumar, R. Exploring dependence of COVID-19 on environmental factors and spread prediction in India. NPJ Clim. Atmos. Sci. 2020, 3, 1-13. [CrossRef]

11. Medicine, J.H.U. CUMULATIVE CASES. 2020. Available online: https://coronavirus.jhu.edu/data/cumulative-cases (accessed on 9 November 2020).

12. WHO. COVID-19 Coronavirus Pandemic. 2020. Available online: https://www.who.int/publications/m/item/weeklyepidemiological (accessed on 11 November 2020).

13. WHO. Naming the Coronavirus Disease (COVID-19) and the Virus That Causes it. 2020. Available online: https: //www.who.int/emergencies/diseases/novel-coronavirus-2019/technical-guidance/naming-the-coronavirus-disease(covid-2019)-and-the-virus-that-causes-it (accessed on 22 April 2021).

14. Van Damme, W.; Dahake, R.; Delamou, A. The COVID-19 pandemic: Diverse contexts; different epidemics-how and why? BMJ Glob. Health 2020, 5, e003098. [CrossRef] [PubMed]

15. Health NIo. Fourth Large-Scale COVID-19 Vaccine Trial Begins in the United States. 2020. Available online: https:/ /www.nih.gov/ news-events/news-releases / fourth-large-scale-covid-19-vaccine-trial-begins-united-states (accessed on 16 December 2020).

16. WHO. Accelerating a Safe and Effective COVID-19 Vaccine. 2020. Available online: https://www.who.int/emergencies/diseases/ novel-coronavirus-2019/global-research-on-novel-coronavirus-2019-ncov/accelerating-a-safe-and-effective-covid-19-vaccine (accessed on 22 April 2021).

17. Han, E.; Tan, M.M.J.; Turk, E.; Sridhar, D.; Leung, G.M.; Shibuya, K.; Asgari, N.; Oh, J.; García-Basteiro, A.L.; Hanefeld, J.; et al. Lessons learnt from easing COVID-19 restrictions: An analysis of countries and regions in Asia Pacific and Europe. Lancet 2020, 396, 1525-1534. [CrossRef]

18. Lu, R.; Zhao, X.; Li, J.; Niu, P.; Yang, B.; Wu, H.; Wang, W.; Song, H.; Huang, B.; Zhu, N.; et al. Genomic characterisation and epidemiology of 2019 novel coronavirus: Implications for virus origins and receptor binding. Lancet 2020, 395, 565-574. [CrossRef] 
19. Adedokun, K.A.; Olarinmoye, A.O.; Mustapha, J.O.; Kamorudeen, R.T. A close look at the biology of SARS-CoV-2, and the potential influence of weather conditions and seasons on COVID-19 case spread. Infect. Dis. Poverty 2020, 9, 1-5. [CrossRef] [PubMed]

20. Edridge, A.W.D.; Kaczorowska, J.; Hoste, A.C.R.; Bakker, M.; Klein, M.; Loens, K.; Jebbink, M.F.; Matser, A.; Kinsella, C.M.; Rueda, P.; et al. Seasonal coronavirus protective immunity is short-lasting. Nat. Med. 2020, 26, 1691-1693. [CrossRef]

21. Liu, D.X.; Liang, J.Q.; Fung, T.S. Human Coronavirus-229E, -OC43, -NL63, and -HKU1. (Coronaviridae). Encycl. Virol. 2021, 2, 428-440. [CrossRef]

22. Fehr, A.R.; Perlman, S. Coronaviruses: An Overview of Their Replication and Pathogenesis. In Coronaviruses: Methods and Protocols; Springer: New York, NY, USA, 2015; Volume 1282, pp. 1-23. ISBN 9781493924387.

23. Satarker, S.; Nampoothiri, M. Structural Proteins in Severe Acute Respiratory Syndrome Coronavirus-2. Arch. Med. Res. 2020, 51, 482-491. [CrossRef]

24. Naqvi, A.A.T.; Fatima, K.; Mohammad, T.; Fatima, U.; Singh, I.K.; Singh, A.; Atif, S.M.; Hariprasad, G.; Hasan, G.M.; Hassan, I. Insights into SARS-CoV-2 genome, structure, evolution, pathogenesis and therapies: Structural genomics approach. Biochim. Biophys. Acta (BBA) Mol. Basis Dis. 2020, 1866, 165878. [CrossRef]

25. Li, G.; Chen, X.; Xu, A. Profile of Specific Antibodies to the SARS-Associated Coronavirus. N. Engl. J. Med. 2003, 349, 508-509. [CrossRef]

26. Long, Q.X.; Liu, B.Z.; Deng, H.J. Antibody responses to SARS-CoV-2 in patients with COVID-19. Nat. Med. 2020, 26, 845-848. [CrossRef]

27. Poland, G.A. Ovsyannikova IG, Kennedy RB. SARS-CoV-2 immunity: Review and applications to phase 3 vaccine candidates. Lancet 2020, 396, 1595-1606. [CrossRef]

28. Emergencies Preparedness, WHO Headquarters (HQ). Diagnostic Testing for SARS-CoV-2; World Health Organization: Geneva, Switzerland, 2020; p. 20.

29. Caygill, R.L.; Blair, G.E.; Millner, P.A. A review on viral biosensors to detect human pathogens. Anal. Chim. Acta 2010, 681, 8-15. [CrossRef] [PubMed]

30. Conroy, P.J.; Hearty, S.; Leonard, P.; O’Kennedy, R.J. Antibody production, design and use for biosensor-based applications. Semin. Cell Dev. Biol. 2009, 20, 10-26. [CrossRef] [PubMed]

31. Ispas, C.R.; Crivat, G.; Andreescu, S. Review: Recent Developments in Enzyme-Based Biosensors for Biomedical Analysis. Anal. Lett. 2012, 45, 168-186. [CrossRef]

32. Liu, J. Oligonucleotide-functionalized hydrogels as stimuli responsive materials and biosensors. Soft Matter 2011, 7, 6757-6767. [CrossRef]

33. Sefah, K.; Phillips, J.A.; Xiong, X.; Meng, L.; Van Simaeys, D.; Chen, H.; Martin, J.; Tan, W. Nucleic acid aptamers for biosensors and bio-analytical applications. Analyst 2009, 134, 1765-1775. [CrossRef]

34. Nguyen, T.; Bang, D.D.; Wolff, A. 2019 Novel Coronavirus Disease (COVID-19): Paving the Road for Rapid Detection and Point-of-Care Diagnostics. Micromachines 2020, 11, 306. [CrossRef]

35. Corman, V.M.; Landt, O.; Kaiser, M.; Molenkamp, R.; Meijer, A.; Chu, D.K.; Bleicker, T.; Brünink, S.; Schneider, J.; Schmidt, M.L.; et al. Detection of 2019 novel coronavirus (2019-nCoV) by real-time RT-PCR. Eurosurveillance 2020, 25, 2000045. [CrossRef]

36. Lephart, P.R.; Bachman, M.A.; LeBar, W.; McClellan, S.; Barron, K.; Schroeder, L.; Newton, D.W. Comparative study of four SARSCoV-2 Nucleic Acid Amplification Test (NAAT) platforms demonstrates that ID NOW performance is impaired substantially by patient and specimen type. Diagn. Microbiol. Infect. Dis. 2021, 99, 115200. [CrossRef]

37. Fomsgaard, A.S.; Rosenstierne, M.W. An alternative workflow for molecular detection of SARS-CoV-2-Escape from the NA extraction kit-shortage, Copenhagen, Denmark, March 2020. EuroSurveillance 2020, 25, 2000398. [CrossRef]

38. Chu, D.K.W.; Pan, Y.; Cheng, S.M.S.; Hui, K.P.Y.; Krishnan, P.; Liu, Y.; Ng, D.Y.M.; Wan, C.K.C.; Yang, P.; Wang, Q.; et al. Molecular Diagnosis of a Novel Coronavirus (2019-nCoV) Causing an Outbreak of Pneumonia. Clin. Chem. 2020, 66, 549-555. [CrossRef] [PubMed]

39. He, J.-L.; Luo, L.; Luo, Z.-D.; Lyu, J.-X.; Ng, M.-Y.; Shen, X.-P.; Wen, Z. Diagnostic performance between CT and initial real-time RT-PCR for clinically suspected 2019 coronavirus disease (COVID-19) patients outside Wuhan, China. Respir. Med. 2020, 168, 105980. [CrossRef] [PubMed]

40. Chow, F.W.-N.; Chan, T.T.-Y.; Tam, A.R.; Zhao, S.; Yao, W.; Fung, J.; Cheng, F.K.-K.; Lo, G.C.-S.; Chu, S.; Aw-Yong, K.L.; et al. A Rapid, Simple, Inexpensive, and Mobile Colorimetric Assay COVID-19-LAMP for Mass On-Site Screening of COVID-19. Int. J. Mol. Sci. 2020, 21, 5380. [CrossRef] [PubMed]

41. Thi, V.L.D.; Herbst, K.; Boerner, K.; Meurer, M.; Kremer, L.P.; Kirrmaier, D.; Anders, S. A colorimetric RT-LAMP assay and LAMP-sequencing for detecting SARS-CoV-2 RNA in clinical samples. Sci. Transl. Med. 2020, 12. [CrossRef]

42. Zhu, X.; Wang, X.; Han, L.; Chen, T.; Wang, L.; Li, H.; Li, S.; He, L.; Fu, X.; Chen, S.; et al. Multiplex reverse transcription loop-mediated isothermal amplification combined with nanoparticle-based lateral flow biosensor for the diagnosis of COVID-19. Biosens. Bioelectron. 2020, 166, 112437. [CrossRef]

43. Broughton, J.P.; Deng, X.; Yu, G. CRISPR-Cas12-based detection of SARS-CoV-2. Nat. Biotechnol. 2020, 38, 870-874. [CrossRef]

44. Velay, A.; Gallais, F.; Benotmane, I. Evaluation of the performance of SARS-CoV-2 serological tools and their positioning in COVID-19 diagnostic strategies. Diagn. Microbiol. Infect. Dis. 2020, 98, 115181. [CrossRef] 
45. Grant, B.D.; Anderson, C.E.; Williford, J.R. SARS-CoV-2 Coronavirus Nucleocapsid Antigen-Detecting Half-Strip Lateral Flow Assay Toward the Development of Point of Care Tests Using Commercially Available Reagents. Anal. Chem. 2020, 92, 11305-11309. [CrossRef]

46. Ragnesola, B.; Jin, D.; Lamb, C.C.; Shaz, B.H.; Hillyer, C.D.; Luchsinger, L.L. COVID19 antibody detection using lateral flow assay tests in a cohort of convalescent plasma donors. BMC Res. Notes 2020, 13, 1-7. [CrossRef]

47. McAulay, K.; Bryan, A.; Greninger, A.L.; Grill, F.; Lake, D.; Kaleta, E.J.; Grys, T.E. Retrospective clinical evaluation of 4 lateral flow assays for the detection of SARS-CoV-2 IgG. Diagn. Microbiol. Infect. Dis. 2020, 98, 115161. [CrossRef]

48. Flower, B.; Brown, J.C.; Simmons, B. Clinical and laboratory evaluation of SARS-CoV-2 lateral flow assays for use in a national COVID-19 seroprevalence survey. Thorax 2020, 75, 1082-1088. [CrossRef] [PubMed]

49. Chaimayo, C.; Kaewnaphan, B.; Tanlieng, N. Rapid SARS-CoV-2 antigen detection assay in comparison with real-time RT-PCR assay for laboratory diagnosis of COVID-19 in Thailand. Virol. J. 2020, 17, 1-7. [CrossRef] [PubMed]

50. Demey, B.; Daher, N.; Francois, C.; Lanoix, J.P.; Duverlie, G.; Castelain, S.; Brochot, E. Dynamic profile for the detection of anti-SARS-CoV-2 antibodies using four immunochromatographic assays. J. Infect. 2020, 81, e6-e10. [CrossRef] [PubMed]

51. Flinck, H.; Rauhio, A.; Luukinen, B.; Lehtimäki, T.; Haapala, A.-M.; Seiskari, T.; Aittoniemi, J. Comparison of 2 fully automated tests detecting antibodies against nucleocapsid N and spike S1/S2 proteins in COVID-19. Diagn. Microbiol. Infect. Dis. 2021, 99, 115197. [CrossRef]

52. Roda, A.; Cavalera, S.; Di Nardo, F.; Calabria, D.; Rosati, S.; Simoni, P.; Colitti, B.; Baggiani, C.; Roda, M.; Anfossi, L. Dual lateral flow optical/chemiluminescence immunosensors for the rapid detection of salivary and serum IgA in patients with COVID-19 disease. Biosens. Bioelectron. 2021, 172, 112765. [CrossRef] [PubMed]

53. Scohy, A.; Anantharajah, A.; Bodéus, M.; Kabamba-Mukadi, B.; Verroken, A.; Rodriguez-Villalobos, H. Low performance of rapid antigen detection test as frontline testing for COVID-19 diagnosis. J. Clin. Virol. 2020, 129, 104455. [CrossRef]

54. Wang, X.; Guo, X.; Xin, Q. Neutralizing Antibodies Responses to SARS-CoV-2 in COVID-19 Inpatients and Convalescent Patients. Clin. Infect. Dis. 2020, 71, 2688-2694. [CrossRef]

55. Meyer, B.; Torriani, G.; Yerly, S. Validation of a commercially available SARS-CoV-2 serological immunoassay. Clin. Microbiol. Infect. 2020, 26, 1386-1394. [CrossRef]

56. Qiu, G.; Gai, Z.; Tao, Y.; Schmitt, J.; Kullak-Ublick, G.A.; Wang, J. Dual-Functional Plasmonic Photothermal Biosensors for Highly Accurate Severe Acute Respiratory Syndrome Coronavirus 2 Detection. ACS Nano 2020, 14, 5268-5277. [CrossRef]

57. Jiao, J.; Duan, C.; Xue, L.; Liu, Y.; Sun, W.; Xiang, Y. DNA nanoscaffold-based SARS-CoV-2 detection for COVID-19 diagnosis. Biosens. Bioelectron. 2020, 167, 112479. [CrossRef]

58. Huang, Z.; Tian, D.; Liu, Y.; Lin, Z.; Lyon, C.J.; Lai, W.; Fusco, D.; Drouin, A.; Yin, X.; Hu, T.; et al. Ultra-sensitive and high-throughput CRISPR-p owered COVID-19 diagnosis. Biosens. Bioelectron. 2020, 164, 112316. [CrossRef]

59. Huang, L.; Ding, L.; Zhou, J. One-step rapid quantification of SARS-CoV-2 virus particles via low-cost nanoplasmonic sensors in generic microplate reader and point-of-care device. Biosens. Bioelectron. 2020, 171, 112685. [CrossRef] [PubMed]

60. Cady, N.C.; Tokranova, N.; Minor, A.; Nikvand, N.; Strle, K.; Lee, W.T.; Page, W.; Guignon, E.; Pilar, A.; Gibson, G.N. Multiplexed detection and quantification of human antibody response to COVID-19 infection using a plasmon enhanced biosensor platform. Biosens. Bioelectron. 2021, 171, 112679. [CrossRef]

61. Seo, G.; Lee, G.; Kim, M.J. Rapid Detection of COVID-19 Causative Virus (SARS-CoV-2) in Human Nasopharyngeal Swab Specimens Using Field-Effect Transistor-Based Biosensor. ACS Nano 2020, 14, 5135-5142. [CrossRef]

62. Alves, D.; Curvello, R.; Henderson, E. Rapid Gel Card Agglutination Assays for Serological Analysis Following SARS-CoV-2 Infection in Humans. ACS Sens. 2020, 5, 2596-2603. [CrossRef]

63. Lin, Q.; Wen, D.; Wu, J.; Liu, L.; Wu, W.; Fang, X.; Kong, J. Microfluidic Immunoassays for Sensitive and Simultaneous Detection of IgG/IgM/Antigen of SARS-CoV-2 within $15 \mathrm{~min}$. Anal. Chem. 2020, 92, 9454-9458. [CrossRef] [PubMed]

64. Vadlamani, B.S.; Uppal, T.; Verma, S.C.; Misra, M. Functionalized TiO2 Nanotube-Based Electrochemical Biosensor for Rapid Detection of SARS-CoV-2. Sensors 2020, 20, 5871. [CrossRef] [PubMed]

65. Ali, M.A.; Hu, C.; Jahan, S. Sensing of COVID-19 Antibodies in Seconds via Aerosol Jet Nanoprinted Reduced-Graphene-OxideCoated 3D Electrodes. Adv. Mater. 2021, 33, 2006647. [CrossRef] [PubMed]

66. Rashed, M.Z.; Kopechek, J.A.; Priddy, M.C. Rapid detection of SARS-CoV-2 antibodies using electrochemical impedance-based detector. Biosens. Bioelectron. 2021, 171, 112709. [CrossRef] [PubMed]

67. Alafeef, M.; Dighe, K.; Moitra, P.; Pan, D. Rapid, ultrasensitive, and quantitative detection of SARS-CoV-2 using antisense oligonucleotides directed electrochemical biosensor chip. ACS Nano 2020, 14, 17028-17045. [CrossRef]

68. Zhao, H.; Liu, F; Xie, W. Ultrasensitive supersandwich-type electrochemical sensor for SARS-CoV-2 from the infected COVID-19 patients using a smartphone. Sens. Actuators B Chem. 2021, 327, 128899. [CrossRef] [PubMed]

69. Ackerman, C.M.; Myhrvold, C.; Thakku, S.G.; Freije, C.A.; Metsky, H.C.; Yang, D.K.; Ye, S.H.; Boehm, C.K.; Kosoko-Thoroddsen, T.-S.F.; Kehe, J.; et al. Massively multiplexed nucleic acid detection with Cas13. Nature 2020, 582, 277-282. [CrossRef] [PubMed]

70. Warren, A.D.; Kwong, G.A.; Wood, D.; Lin, K.Y.; Bhatia, S.N. Point-of-care diagnostics for noncommunicable diseases using synthetic urinary biomarkers and paper microfluidics. Proc. Natl. Acad. Sci. USA 2014, 111, 3671-3676. [CrossRef] [PubMed]

71. Qin, Z.; Peng, R.; Baravik, I.K.; Liu, X. Fighting COVID-19: Integrated Micro- and Nanosystems for Viral Infection Diagnostics. Matter 2020, 3, 628-651. [CrossRef] [PubMed] 
72. WHO. Coronavirus Disease (COVID-19) Dashboard. 2020. Available online: http:/ /www.emro.who.int/bahrain/informationresources/covid-19-situation-reports.html (accessed on 20 December 2020). 